\title{
AN ANALYSIS OF FACTORS AFFECTING JOB SATISFACTION OF WOMEN IN PAID EMPLOYMENT IN BENIN CITY
}

\author{
OFUANI Mrs, Felicia Ngozi \\ Department Of Educational Psychology and Curriculum Studies \\ University Of Benin \\ email: ofuaniogo@yahoo.co.uk
}

\begin{abstract}
This study examined the job satisfaction of women in paid employment in Benin City. The purpose of this study was to find out whether women in paid employment are satisfied with their jobs or not and to establish the effects of marital status, experience, academic qualification and relationship with superior officers of the women on their perception of job satisfaction. A sample of two hundred women was selected using the stratified random sampling and the data instrument was a questionnaire called 'Job Satisfaction of Women in Paid Employment Questionnaire (J.S.W.P.E.Q). Data collected were analysed using the t-test. The result of the study revealed that marital status, experience, academic qualification and relationship with superior officers had no significant effect on the job satisfaction of women in paid employment in Benin City. It is recommended that women should be given opportunities to hold positions of responsibility and conducive atmosphere should be created for them at their work places.
\end{abstract}

Key Words: Women, Job Satisfaction, Employment, Stereotype, Benin City.

\section{Introduction}

In the present day Nigeria, women have become a force to be reckoned with in the labour market. Until recently, women were stereotyped into social roles as wives, mothers, cooks and so forth. When women started taking paid employment, it was generally believed that they would do well as teachers and nurses, jobs that are related to their stereotyped social roles. Women, however, have gone into 'male-dominated jobs' like piloting, medicine and engineering. 
Women's participation in the labour force is on the increase. This is as a result of increased women education, training, urbanization and the demands of the present day economy in Nigeria.

The economic conditions prevalent in the country presently are very depressive. Many workers are frustrated because of constant threats of retrenchment, rationalization and the need to meet up with the present day economic pressures. Workers generally complain of lack of job satisfaction in their jobs, mostly because of inflationary trends. Most workers, especially women, have taken to private practice while in government employment. This situation is likely to heighten their truancy in their work places. In the light of these problems of retrenchment, one begins to wonder whether women in paid employment are currently satisfied with their jobs.

From 1973, the Federal Government has tried in various ways to review workers' salaries and give workers incentives. It seems that all the efforts made by the government to increase workers' salaries and allowances are not felt because of inflationary trends hence most workers seem generally not satisfied with their work. Therefore, agitation for wage increase is likely to continue.

Ajayi (1983) sees job satisfaction as the personal feelings of contentment or a compound of various attitudes, mental and emotional, which a worker has and exhibits toward his work situation. Gruneberge (1979) refers to job satisfaction as an individual's emotional reactions to a particular job. Weiss (2002) has argued that job satisfaction is an attitude but points out that researchers should clearly distinguish the objects of cognitive evaluation which affect emotion, beliefs and behaviours. That is to say that we form our attitude towards our jobs by taking into account our feelings, our beliefs and our behaviours.

Job satisfaction is the effective orientation of individuals towards work roles that they are currently occupying. One could be said to be satisfied with one's job to the extent that the job fulfils one's dominant needs and values (Rextroat, 1992; Usman 2005; and Clark, 2006)..

This study sought to find out the effects of certain variables on the job satisfaction of women in paid employment in Benin City. In order to carry out this study, the following hypotheses were postulated;

1. Women in paid employment in Benin City are not generally satisfied with their jobs.

2. Marital status has no significant effect on the job satisfaction of women in paid employment. 
3. Experience has no significant effect on the job satisfaction of women in paid employment.

4. Academic qualification has no significant effect on the job satisfaction of women in paid employment.

5. The relationship with superior officers has no significant effect on the job satisfaction of women in paid employment.

\section{Statement of the Problem}

Job satisfaction is dynamic; it is a condition where individuals are contented or discontented with their jobs. Lack of job satisfaction could lead to strikes, work to rule, absenteeism, resignation, low performance and disciplinary problems. Intrinsic and extrinsic variables such as the structure and nature of jobs, the type of control, supervision, participation in decision making, pay, promotion, fringe benefits, and working conditions affect the job satisfaction of an individual. The current inflationary trends and the fact that many women have resorted to different ways to make ends meet may be an indication that they are not satisfied with their jobs.

\section{Significance of the Study}

The study of job satisfaction and dissatisfaction is very crucial not only for the enhancement of productivity but also for the fulfilment of the needs of the individuals in an organization. This is obvious when it is realised that one spends a reasonable part of one's working life at the work place. Research into job satisfaction among women would provide information and knowledge in the area of the job satisfaction of women. It would highlight what constitute the determinants of the job satisfaction of women.

To understand workers' job satisfaction is an important aspect of learning to manage an organization. Information from this study would help and guide employers of women in paid employment to discover and reinforce what would satisfy women workers and check factors that would lead to dissatisfaction and frustration in their jobs.

\section{Method of Study}

This study is a survey of job satisfaction of women in their jobs. It tries to find out the effects of marital status, experience, academic qualification and relationship with superior officers on the job satisfaction of women in paid employment in Benin City.

The population of the study was nine thousand four hundred and eighteen $(9,418)$ women, made up of all the female workers in the civil 
service and the female teachers in the primary and secondary schools in Benin City (Edo State Government 2008). Two hundred (200) women in eight (8) professions were selected using the stratified random sampling technique. These eight professions include teaching, pharmacy, law, nursing, lecturing, medicine, secretarial, and civil service administration. Twenty five (25) women were selected in each profession. A table of random numbers was used in the study.

The instrument used in the study was a questionnaire, the 'Job Satisfaction of Women in Paid Employment Questionnaire (J.S.W.P.E.Q) made up of thirty one items and divided into two sections. The first section consists of eleven items which dealt with the demographic variables of marital status, age, level of education, number of children and years of job experience. The second section of the questionnaire dealt with the level of job satisfaction of women. It was made up of questions that dealt with work itself, salary, creativity and autonomy on the job.

Pearson's Product Moment Correlation Co-efficient ( $r$ ) was used to determine the reliability co-efficient of the instrument. The computed value was 0.85 . The Likert type of scale with a continuum of 1-5 was used in scoring the twenty (20) items on the questionnaires. The data collected were analysed using means and t-test.

\section{Result}

Hypothesis 1: This states that women in paid employment are not satisfied with their jobs.

Table 1: Distribution of Women by Score Group

\begin{tabular}{|l|c|}
\hline Satisfaction Score & Frequency \\
\hline Less than 60 points score & 72 \\
\hline 60 points score & 5 \\
\hline Above 60 points score & 117 \\
\hline Total score & 194 \\
\hline
\end{tabular}

March 2009

On the whole, one hundred and ninety four (194) women were used. There was a maximum possible score of 100 points for the twenty (20) items of section B of the J.S.W.P.E.Q. questionnaire. The midpoint score was $60 \%$. To be classified as satisfied with a job, a woman worker in paid employment must score 60 points and above in the questionnaire while the score of less than $60 \%$ classified the woman as being dissatisfied with her job. 
From Table 1, a total number of one hundred and seventeen (117) women scored above 60 points. This shows that women in paid employment are generally satisfied with their jobs, and the hypothesis which stated that women in paid employment in Benin City are not satisfied with their jobs was rejected.

Hypothesis 2: This states that the marital status has no significant effect on job satisfaction of women in paid employment.

In testing this hypothesis, a t-test analysis was undertaken. From Table 2, the t-test for significant difference between job satisfaction of married and single women was sought.

Table 2: The Effect of Marital Status on Job Satisfaction of Women in Paid Employment

\begin{tabular}{|l|c|c|c|c|c|c|}
\hline \multicolumn{1}{|c|}{ Variable } & No & $\bar{X}$ & SD & df & T & P \\
\cline { 1 - 3 } Married & 134 & 63.4 & 9.89 & \multirow{2}{*}{192} & \multirow{2}{*}{0.73} & $\begin{array}{c}\text { Not } \\
\text { significant }\end{array}$ \\
\hline Not married & 60 & 62.4 & 10.91 &
\end{tabular}

$$
{ }^{*} \mathrm{t} \text { critical }=1.980
$$

The analysis of data presented in table 2 revealed that the calculated value 0.73 was less than the table value of 1.980 . Therefore, there was no significant difference. The hypothesis that marital status has no significant effect on job satisfaction of women in paid employment was retained. Women in paid employment, irrespective of marital status, are satisfied with their jobs.

Hypothesis 3: This states that experience has no significant effect on the job satisfaction of women in paid employment.

To test this hypothesis, the women were grouped into two: women with little experience ( $0-5$ years) and women with more experience ( 5 years and above). The data obtained from the responses of these women were analyzed using the $t$-test of independent means. The result obtained is presented in Table 3 .

Table 3: The Effect of Experience on Job Satisfaction of Women in Paid Employment

\begin{tabular}{|l|c|c|c|c|c|c|}
\hline \multicolumn{1}{|c|}{ Variable } & No & $\bar{X}$ & SD & df & T & P \\
\cline { 1 - 4 } Experience & 147 & 63.69 & 10.20 & \multirow{2}{*}{192} & \multirow{2}{*}{0.07} & $\begin{array}{c}\text { Not } \\
\text { significant }\end{array}$ \\
\cline { 1 - 3 } In experience & 47 & 63.65 & 11.60 & &
\end{tabular}


Table 3 shows that the table value was 1.980 while the calculated value was 0.07 . As a result of this, there was no significant difference. The hypothesis which stated that experience has no significant effect on the job satisfaction of women in paid employment was retained. Women in paid employment, irrespective of the years they spent on their jobs, are satisfied.

Hypothesis 4. This states that academic qualification has no significant effect on the job satisfaction of women in paid employment.

Table 4: The Effect of Academic Qualification on the Job Satisfaction of Women Workers

\begin{tabular}{|l|c|c|c|c|c|c|}
\hline \multicolumn{1}{|c|}{ Variable } & No & $\bar{X}$ & SD & df & T & P \\
\hline Educated & 120 & 63.92 & 11.53 & 192 & 0.89 & $\begin{array}{c}\text { Not } \\
\text { significant }\end{array}$ \\
\hline Less educated & 74 & 63.34 & 12.26 & & & \\
& \multicolumn{7}{c}{ critical $=1.980$}
\end{tabular}

Table 4 shows that the table value was 1.98 while the calculated value was 0.89 . Since the calculated value was less than the table value, there was no significant difference. The hypothesis that academic qualification has no significant effect on the job satisfaction of women in paid employment was retained. Women, irrespective of their educational backgrounds, are satisfied with their jobs.

Hypothesis 5: This states that the relationship with superior officers has no effect on the job satisfaction of women in paid employment.

To test this hypothesis, a t-test analysis of two independent mean was undertaken. Table 5 below shows the significant difference between cordial relationship and non cordial relationship.

Table 5: Effects of Relationship with Superior Officers on Job Satisfaction

\begin{tabular}{|l|c|c|c|c|c|c|}
\hline \multicolumn{1}{|c|}{ Variable } & No & $\bar{X}$ & SD & df & $\mathbf{t}$ & P \\
\hline Cordial & 188 & 62.13 & 9.83 & \multirow{2}{*}{192} & 1015 & $\begin{array}{c}\text { Not } \\
\text { significant }\end{array}$ \\
\cline { 1 - 3 } Non cordial & 6 & 57.67 & 10.62 & & \\
\hline \multicolumn{7}{|c}{ t-critical $=1.98$}
\end{tabular}

Table 5 shows that the calculated value was less than the table value. There was therefore no significant difference. The hypothesis which stated that the relationship with superior officers had no 
significant effect on the job satisfaction of women in paid employment was retained.

\section{Discussion}

One of the findings of this study was that women in paid employment are satisfied with their jobs. During the analysis of data, the women were categorized into three groups: women who scored less than $60 \%$ which was the mid-point score; women who scored $60 \%$; and women who scored above $60 \%$. It could be argued that these women entered their different jobs with different personal biases and were able to adjust to the demands of their jobs. This finding is in consonance with the findings of Ajayi (1983), McNeely (1984), Rextroat (1992), Mi'ari (1996), Chukwuma (2006) and Clark (2006). Chukwuma (2006) found that female teachers are more satisfied than male teachers in their jobs.

This study found that experience had no significant effect on the job satisfaction of women in paid employment. One would have expected that job satisfaction would have increased by the experience of the workers so the women who have stayed more years in their jobs would be more satisfied than women with little experience in the same job. The findings of this study are in agreement with those of Clark (2006) and Usman (2006), who found that experience had no significant effect on the job satisfaction of teachers.

It was expected that academic qualification would have significant effects on the women's perception of job satisfaction. The professionally trained women are expected to be more satisfied than their nonprofessionally trained colleagues. This is because the former had the advantage of training and qualification. However, the findings of this study turned out to show no significant effect. This finding is not in consonance with the findings of Saiyandain (1979), Abu-Bader (2002), Gardner and Oswald (2002), Clark (2006), and Alao et al (1989). Alao et al (1989) found lower job satisfaction score for counsellors with postgraduate qualifications than those with only first degrees. Also Clark (2006) found significant differences in the job satisfaction and educational qualification of her respondents. She found that highly educated teachers with postgraduate qualifications were less satisfied with their jobs.

It was also found that marital status has no significant effect on the job satisfaction of women in paid employment in Benin City. One would have expected that a married woman with children and most likely more responsibilities would have different work values from a spinster. The findings of this work is in agreement with the work of Ajayi 
(1983), Iremiren (1986), Usman (2006) and Clark (2006) that job satisfaction was independent of marital status.

This study found that the relationship with superior officers had no effect on the job satisfaction of women, which is not in agreement with those of Schuler (1975) and Abu-Bader (2002) who found that women value the opportunity to work with pleasant superior colleagues.

\section{Conclusions}

Based on the findings of this study, the following conclusions were drawn:

- Women in paid employment in Benin City are satisfied with their jobs.

- Marital status, experience, academic qualification, and relationships with superior officers have no significant effects on the job satisfaction of women in paid employment in Benin City.

\section{Recommendations}

Based on the findings of this study, the following recommendations are made:

1. Women in paid employment should be encouraged in their work places because working gives them satisfaction.

2. Deserving women should be given opportunities to hold responsible positions because these meet their self-esteem and self-actualization needs.

3. Pleasant working atmosphere should be provide because women cherish cordial relationship with their employers.

\section{References}

Abu-Barder, S.H. (2002). Gender, ethnicity, and job satisfaction among social workers in Israel. A paper presented at the $48^{\text {th }}$ annual program meeting, Council in Social Work Education, February 2427, 2002, Nashville, TN.

Ajayi, K.A. (1983). The relationship between job satisfaction and productivity among junior workers in a service oriented enterprise. Psychology for Everyday Living (2), p. 133.

Alao, K.A., Olaniyi, G.B. and Kobiowu, S.B. (1989). Sex, academic qualification and job satisfaction of Nigerian professional counsellors: Implication for professional helping in developing society. Nigerian Journal of Counselling Development Vol. 14, pp. $157-162$. 
Buka, K. and Buba, S.D. (2006). Teachers' job satisfaction and academic achievement in Gombe State senior secondary schools, Nigeria. International Journal of Research in Education 3(1), pp. 228-234.

Chukwuma, E. (2006). Teaching profession and gender job satisfaction: A study of teachers in Enugu State school system. International Journal of Research in Education 3(2), pp. 39-43.

Clark, A.O. (2006). Teacher job satisfaction: Antidote for inefficiency and poor performance. African Journal of Studies in Education 2(1), pp. 133-147.

Edo State of Nigeria (2008). Staff list as at December 2007, showing date of retirement. Benin City: Governor's Office, Edo State Government.

Gardner, J. and Oswald, A. (2002). How does education affect mental wellbeing and job satisfaction? Social Research Conference, University of Birmingham.

Gruneberge, M.M. (1979). Understanding job satisfaction. London: Macmillan Press.

Iremiren, F.O. (1986). Job satisfaction among nurses: Case study of Central Hospital, Benin City and the University of Benin Teaching Hospital, Benin City. Unpublished Masters Thesis, University of Benin, Benin City.

McNeely, R.L. (1984). Occupation, gender, work satisfaction in a comprehensive human services department. Administration in Social Work (2), pp. 35-47.

Mi'ari, (1996) Work satisfaction and gender. International Review of Modern Sociology, 26(1), pp. 67-69.

Rextroat, C. (1992). Change in the employment continuity of succeeding cohorts of young women. Work and Occupation 19(1), pp. 18-34.

Saiyandain, M. (1979). Know your satisfied employers. Management in Nigeria 15(8), pp. 40-42.

Usman, A. (2005). Relationship between teachers' job satisfaction and job performance in Borno State secondary schools. Unpublished M.Ed Dissertation, University of Maiduguri.

Weiss, H.M. (2002). Deconstructing job satisfaction: Separating evaluation, beliefs and affective experiences. Human Resources Management Review 12, pp. 173-194. 